\title{
Collective Progress in Academic Librarianship
}

As we anticipate the fast-approaching unfolding of ACRL's Second National Conference in Minneapolis in October, it seems an appropriate time to review briefly the early and more recent development of the Association.

It has been nearly a century since thirteen college and university librarians gathered informally at the 1889 ALA Conference in St. Louis to discuss their shared sense of a need for a forum in which to consider matters peculiar to college libraries.

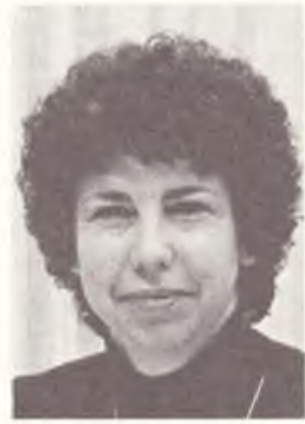

Millicent D. Abell Voting on a motion by Amherst librarian W. I. Fletcher, the thirteen took the first step toward the formation of ACRL, an association that nevertheless was some fifty years a-borning. ${ }^{1}$

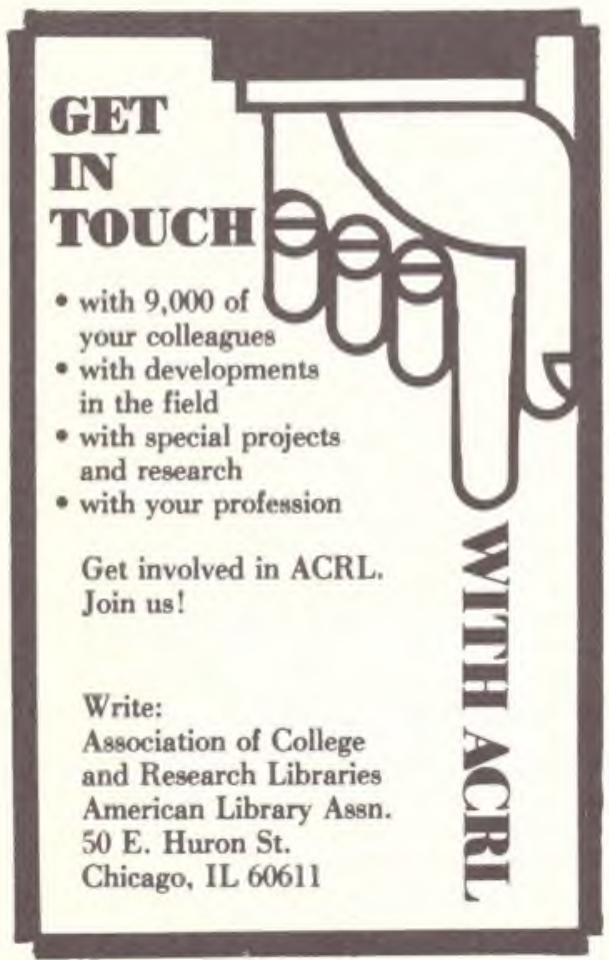

In contrast to its prolonged gestation period, ACRL's forty-three years of life since its official formation in Kansas City in 1938 have been years of steady progress. For the past 11 of those years I have witnessed first hand ACRL's gathering momentum and maturity as a professional association. My experiences in the past year as president of the Association have convinced me that ACRL has evolved into a particularly valuable structure and cohesive force for academic librarians.

The programs planned or carried out by the Association this year have derived directly from the expressed needs and interests of its members. Among the newest of these is the ACRL program of continuing education courses just launched at the San Francisco ALA Conference. The CE program has as its goal the development of high quality courses grouped in five tracks and building upon one another within the tracks. The five tracks in which courses are being developed to meet the current needs of academic librarians are:

\section{Management \\ II. Library Skills \\ III. Technology Update \\ IV. The Environment \\ V. Professional Development}

A second forward-looking ACRL effort undertaken in the past year has been the "ACRL Activity Model for 1990." Initiated by David C. Weber. the Association's vice-president/presidentelect, the Activity Model program consists of several steps

1. After widespread gathering of suggestions and contributions, a small committee will draft a plan for ACRL program activities toward the end of this decade.

2. The draft plan will be discussed by ACRL groups at the midwinter meeting of 1982 , after which the final document will be published.

The objective of the "Activity Model for 1990" program has been expressed succinctly by David Weber: "To help shape the directions of efforts in the vears inmediately ahead, to raise therely the sights of ACRL members and Sections and

${ }^{1}$ William H. Carlson, "Origins and Development of ACRL," College and Research Libraries Neus 32 (June 1971): 155-60. 
officers for achievement of the Association, and to stimulate membership interest in involvement in the advancing of the Association toward these goals."

A third new ACRL program to emerge in the past year is the series of regional collection management and development institutes co-sponsored by ACRL and ALA's Resources and Technical Services Division.

A fourth area of special focus in ACRL programs this year has been the strengthening of the Association's liaison with groups in higher education. The Board has authorized a new part time position to facilitate such liaison, particularly to promote bibliographic instruction. This year, for the first time, the ACRL liaison serves on the Board of Directors of the American Council on Education (ACE), a non-profit association which serves as both the nation's major coordinating body for post-secondary education, and the major voice of American higher education in Washington. ACRL's delegate to ACE this year has been Russell Shank. A particularly gratifying result of his efforts as delegate has been the commitment by ACE to a program session on libraries at the next annual $\mathrm{ACE}$ conference in Washington, D.C., in October 1981 .

ACRL's ties with higher education were further enhanced this year through the Association's program meeting at the San Francisco conference, "Scholars and Librarians: Partners in Learning and Research." The program highlighted the interaction among the groups and individuals who have a commitment to higher education, and thus drew our attention once again to our fundamental mission as academic librarians.

While new areas of emphasis emerged within ACRL this year, other ongoing programs of value were sustained. One of those, the Academic Librarian of the Year Award, brought a moment of special satisfaction to all those who witnessed the presentation of this award for 1981 to a former ACRL Executive Secretary, Beverly Lynch, at the ACRL reception in Berkeley. The Baker and Taylor Company generously continues to underwrite this award.

Essential continuing programs have included Fast Job Listing Service and the JOBLINE; both provide librarians and libraries with a vital service on a timely basis. The same is true of the Association's publications program, a recent and worthwhile addition to which is the CLIP Note series issued by the College Libraries Section's Continuing Education Committee.

The energy and productivity of the Association is directly dependent on widespread and effective involvement of the membership. It has been gratifying to me to see significant members of academic librarians newly involved each year in regional and national ACRL activities. Equally gratifying have been the thoughtful deliberation and positive actions taken by the restructured
Board of Directors.

ACRL's progress in developing new programs and sustaining existing ones is due in no small way to the skill and dedication of its headquarters staff. Association members are most fortunate to have their business administered by the capable team of Julie Virgo, Executive Director, $\mathrm{Hal}$ Espo, Deputy Executive Director, and their associates in the ACRL office.

In addition to growth in its programs, the Association has experienced growth in its membership in the past year. The approval at Midwinter conference for the establishment of chapters in Mississippi, Ohio and South Dakota brought the total number of ACRL chapters in the United States and Canada to an all-time high of 29 . With 8,710 members, 7,327 of whom are personal memberships, the Association still ranks as the largest of the ALA divisions.

Needless to say, the vitality and effectiveness of the Association does not come free. Although there have been a number of successful efforts to diversify income sources, to establish selfsustaining services, and to trim costs, we still are facing a fiscal crisis. ACRL is no more immune to the effects of inflation than are our libraries; thus, after seven years of an unchanged dues structure, the Board of Directors has endorsed a $\$ 10.00$ per year dues increase for personal membership, effective with the 1982 calendar year. This action will require approval by a majority of the ACRL voting membership in a mail ballot this summer.

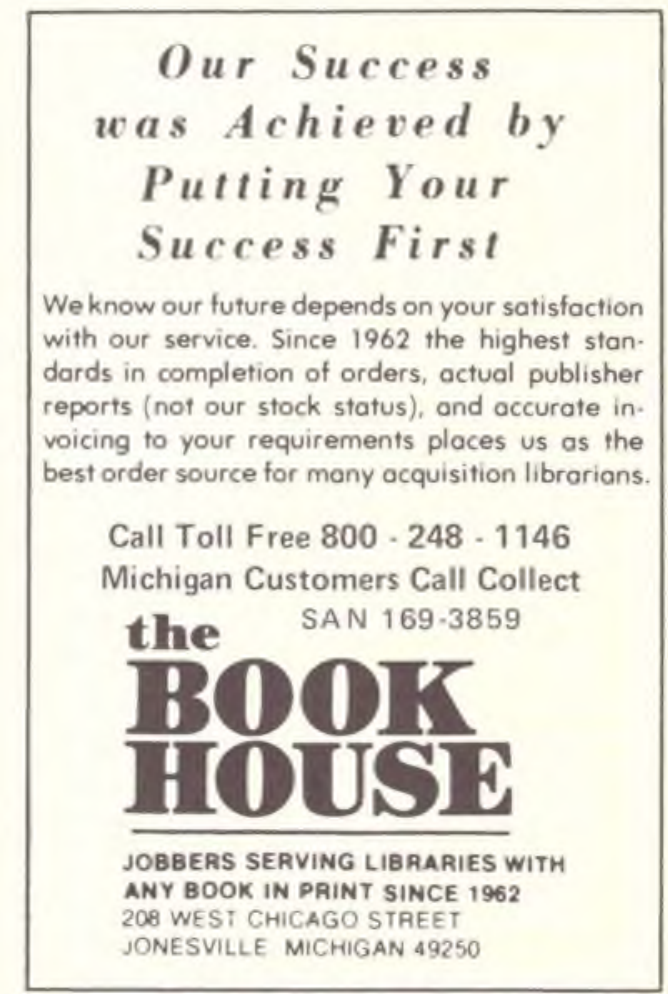


I urge all ACRL members to support this step, recognizing it for what it is: an investment in the future of academic libraries and librarianship.

In his eloquent report last year my predecessor reported on a number of serious issues which we continue to confront. Progress has been made on a number of them. The most significant expenditure of effort during the year has been the attempt to affect the development of a new "Operating Agreement for ALA and its Divisions." This Agreement will affect both the governance and the financing of the ACRL, the other divisions, and the ALA central structure. The ACRL objective in various forums has been to maximize the ability of ACRL to meet the needs of its members without undermining the essential services of the ALA central structure. There are embedded in the negotiations issues which may never be fully resolved. Certainly the relationships are dynamic ones. However, we do expect that some of the basic issues will be settled in the Agreement scheduled to be adopted at the Midwinter Conference in 1982.

Ninety-two years have passed since Mr. Fletcher made his motion for the formation of an association of academic librarians. Since that time, the collective efforts of academic librarians to advance our profession and the association that sustains it have borne results that, I believe, effectively disprove Baudelaire's contention that there can be no progress except in the individual.

Millicent D. Abell President, ACRL

\section{Bibliographic Instruction}

\section{Bibliographic Competencies for Education Students}

Students in education need an increasingly sophisticated knowledge of library resources in order to access information in the discipline. "Bibliographic Competencies for Education Students," an ACRL committee project, identifies minimal skills in the use of education materials which should be demonstrated by students at the undergraduate and graduate levels. It is intended for use by students, teaching faculty, and librarians.

Members of the Bibliographic Instruction for Educators Committee of ACRL's Education and Behavioral Sciences Section who developed the instrument are: George Jaramillo, Jim Olivetti, Virginia Parr, Hannelore Rader, Ilene Rockman, Harvey Soule, Charles Thurston, Thomas Tollman, and Joan Worley (chair).

1. To develop a logical approach to researching a topic.

a. Locate definitions of general and specialized educational terms. Information sources: Dictionary of Education; International Dictionary of Education; Terms in Reading. Rationale: To recognize dictionary sources specific to education.

b. Locate summary discussions of educational topics. Information sources: Encyclopedia of Education; Handbook on Contemporary Education. Rationale: To gain overview of topics of inquiry and learn secondary sources of research.

c. Locate resources using the library's author, subject, and title catalog(s). Information sources:
Card, Online, Fiche or Film Catalog. Rationale: To gain access to a library's holdings.

d. Locate journal articles in indexes and abstracts. Information sources: Education Index; Current Index to Journals in Education (CIJE); Child Development Abstracts and Bibliography; Educational Administration Abstracts. Rationale: To access periodical literature in education.

2. To identify major reference tools in education. Information sources: Encyclopedia of Educational Research; Second Handbook of Research in Teaching; Resources in Education. Rationale: To perform basic bibliographic research in support of teaching.

3. To identify and describe standardized tests. Information sources: Mental Measurements Yearbook; Directory of Unpublished Experimental Mental Measures. Rationale: To become acquainted with the characteristics of tests in use.

4. To locate and describe print and non-print curriculum materials, instructional aid resources. Information sources: Curriculum Review; Media Review Digest; NICEM Directories; Educators Guides to Free Films, etc. Rationale: To locate critical reviews of classroom materials, to effectively access audiovisual and graphic aids in instruction.

5. To locate book reviews in education and related fields. Information sources: Book Review Digest; Current Book Review Citations. Rationale: To access critical commentary on books and authors in education. 